\title{
Factors Affecting for Loan Defaults with Special Reference to State Commercial Banks
}

\author{
W.D.M.B.K. Dissanayake ${ }^{1} \&$ P.S.N. Samarathunga ${ }^{2}$ \\ ${ }^{1,2}$ Department of Business Management \\ Faculty of Business Studies \& Finance \\ Wayamba University of Sri Lanka \\ Kuliyapitiya \\ SRI LANKA \\ bimba@wyb.ac. $\mathrm{k}^{1}$
}

\begin{abstract}
Financial system stability is one of the key fundamentals upon which economic growth is based. Most developing countries' financial system is dominated by the banking sector. Commercial banks constitute the anchor of the growth of other sectors by providing them access to credit facilities in the form of loans consequently, the soundness of the banking industry is an essential consideration for financial system stability. Though there were many research studies published in the banking sector for enhancing customer loyalty, there is limited consideration to identify reasons for non-performing loans in the banking sector in Sri Lanka. Thus this study was conducted to assess factors affecting loan defaults in addressing the aforementioned gap. The quantitative research approach was adopted for the study. A survey was conducted with professionals engaged in two state-owned commercial banks using a self-administrative questionnaire. A convenient sampling procedure was used to obtain 164 responses from customers. Correlation and multiple regressions were used to investigate the relationship between dependent and independent variables. The finding of the study shows that economic factors, and institutional factors to the causes of loan default. The research proved that institutional factors and economic factors impacted loan defaults. The findings of the study suggest to the bank managers, loan officers, recovery officers, and other staff members to pay attention to credit terms, monitoring, inflation rates, and the income of the customers when they grant loans for new customers. The findings of this study will aid the management to improve their management of non-performing loans, encourage bank managers to participate more in policy formulation at the micro and macro levels as far as bad debt management is concerned, and also to diversify bank's investment portfolios.
\end{abstract}

Keywords: Non-performing loans, Commercial Banks, Sri Lanka 


\section{INTRODUCTION}

Banks exist to provide financial intermediation services while at the same time endeavor to maximize profit and shareholders' value. Lending is considered the most important function for fund utilization of commercial Banks as a major portion of their income is earned from loans and advances (Radha, 1980). Despite the fact that loan is a major source of banks income and constitutes their major assets, it is a risky area of the industry. That is also why credit risk management is one of the most critical risk management activities carried out by firms in the financial services industry. In fact of all the risks banks face, credit risk is considered the most lethal as bad debts would impair a bank's profit. It has to be noted that credit risk arises from uncertainty in a given counterparty's ability to meet its obligations is accepted. A rapid build-up of bad loans plays a crucial role in banking crises (Demirgüç-Kunt \& Detragiache, 1998; GonzálezHermosillo, 1999). A high level of non-performing loans is linked to bank failures and financial crises. Failure in one branch might lead to failure of the bank and failure in one bank might lead to run on bank which in turn has a contagious impact affecting the whole banking industry.

In the Sri Lankan context, the low asset quality of commercial banks is more emphasized when compared that with the developed countries (World Bank, 2014). Sri Lanka has experienced a distressing situation in the number of commercial banks by recording high non-performing loans showing the early indicators of problematic bank practices that could have led to bank failures.

In the researcher's context of the study, the banks are facing a high amount of loan defaults amounted to 10 percentages of non-performing loan ratios. These banks have 30 years of history in lending operations and currently, each bank is granting more than 200 loans per month. Though they have been preparing action plans to reduce the non-performing loans, they have failed to reach an acceptable level which has made the situation. The non-performing loan amounts since 2009 up to 2014 are indicated in figure 1 .

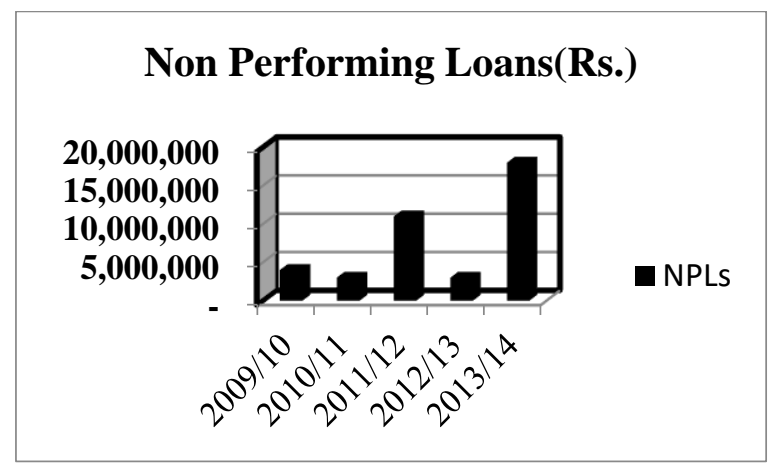

\section{Figure 1. Non-Preforming Loans for the period 2009-2014}

Though there were a number of research studies published in the banking sector for enhancing customer loyalty, there is limited consideration to identify reasons for non-performing loans in the banking sector in Sri Lanka. Thus this study was conducted with the aim of assessing factors affecting loan defaults in addressing the aforementioned gap. 
To address the aforesaid research problem, the following research questions were developed;

- What are the factors affecting loan defaults?

- What is the degree of impact of those factors on loan defaults?

The research was executed to find answers to the above-mentioned research questions through achieving the objectives of finding out which factors impact loan defaults and what is the degree of impact of those factors on loan defaults.

The study focuses on the nonperforming loans in the state commercial banks in the Kegalle district with particular focus on the bank of Ceylon Kegalle super grade branch and people's bank Kegalle.

A non-performing loan occurs when payments of interests and principal are past due by 90 days or more, or at least 90 days of interest payment have been capitalized, delayed by agreement, or payments are less than 90 days overdue (IMF, 2009).

Woo (2000) supposed that, on the macroeconomic assumption, nonperforming loans are a typical signal of the financial crisis. Rising interest rates, economic slowdowns, currency exchange rate depreciation can even severely deteriorate the phenomenon of nonperforming loans. Understanding the causes and consequences of non-performing loans is a crucial prerequisite to tackle the non-performing loans phenomenon. Besides, the objective of managing non-performing loans is also a critical element. Nonperforming loan management, or credit risk management in the banking sector, is a process of formation and conduction of policies to attain objectives. The objectives of managing nonperforming loans focus on hedging the expansion of nonperforming loans, combining with solving current non-performing loans (Woo, 2000).

Warue (2013) identified that lending interest rates are positive and significantly related to nonperforming loans in commercial banks. Jimenez \& Saurina (2006) also showed similar results found a significant and positive relationship between the market interest rate and problem loans. Warue (2013) concluded that inflation has a negative impact on government commercial banks. Empirical studies tend to confirm a positive link between the nonperforming loans and the unemployment rate of the economy. (Nkusu, 2011) explains that unemployment reduces the level of income that individuals obtain thereby increasing their debt burden. Loss of job or increased unemployment makes it hard for the affected individuals with outstanding loans to service the loans. it was identified that speculation: such as investing in highrisk assets to earn a high income and also fraudulent practices such as advancing loans to ineligible persons or advances without security or reference as some of the causes of non-performing loans. According to Gorter \& Bloem (2002), unsettled loans are mainly caused by an inevitable number of wrong economic decisions by individuals. Further, it was claimed that non-performing loans may be caused by poor 
management, poor supervision, and over-optimistic assessment (Bloem \& Gorter, 2001; Berger \& De Young, 1997). Ahmad, (2002), mentioned some important factors that cause loan defaults which include; lack of willingness to pay loans coupled with the diversion of funds by borrowers, willful negligence, and improper appraisal by Credit Officers.

Based on aforesaid facts the researcher constructed a conceptual framework that provides empirical predictions and highlights important issues for this analysis as depicted below;

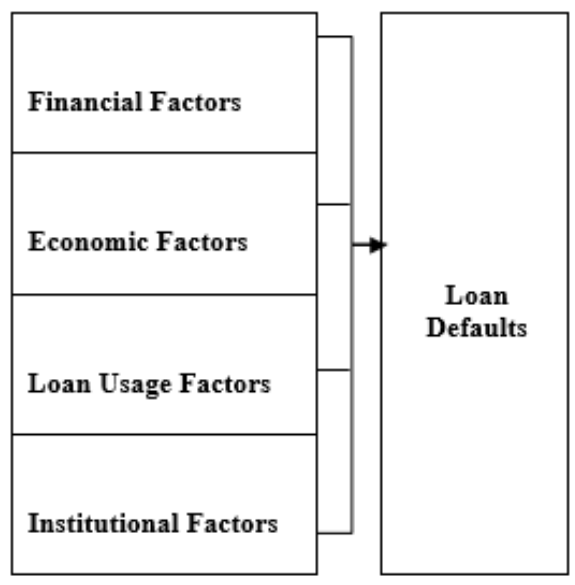

Figure 2. Conceptual Framework

Based upon prevailing literature and in alignment with the conceptual framework following hypotheses were constructed;

$\mathrm{H}_{1}$ : Financial factors have a significant impact on loan defaults $\mathrm{H}_{2}$ : Economic factors have a significant impact on loan defaults $\mathrm{H}_{3}$ : Loan usage factors have a significant impact on loan defaults $\mathrm{H}_{4}$ : Institutional factors have a significant impact on loan defaults

\section{METHODS}

This research adopted a quantitative approach. The research used a survey strategy to collect primary data using a self-administered questionnaire fallen into a cross-sectional study where data was collected just once at a particular time.

The customers who have not paid the borrowed loans from the two banks in Kegalle district composite the population for the study where 180 customers were selected as the sample using a convenience sampling technique. A self-administered questionnaire was distributed among the sample and 166 responses were received. The response rate was 92 percent $(92 \%)$.

The questionnaire was distributed in both English and Sinhala languages for the customers as per their preference. Questionnaires part (A) consist of questions regarding general information and part (B) consists of questions related to financial factors, economic factors, institutional factors, and loan default factors. In the questionnaire, part (A) consists of 5 questions regarding general information, part (B) consists of 18 questions related to financial factors, economical factors, loan default factors, and institutional factors, (1-4) related to financial factor, (5-8) related to the economic factors, (9-12) related to loan usage factors, (14-17) related to institutional factors and (18-19) related to loan defaults factors.

After collecting, the data was edited, classified, coded, and tabulated. Quantitative data were analyzed using 
a statistical package for social science. Pearson's correlations analysis, simple regression, and multiple regression analysis were used to analyze the data. To achieve the objective of the study, a model was developed using causes as independent variables \& loan defaults as the dependent variable. The extent to which non-performing loans (loan defaults) have impacted state banks in the Kegalle district was analyzed using multiple regression analysis.

\section{RESULTS}

The proposed regression model for the present study can be expressed as follows.

$Y_{L D}=\beta 0+\beta 1 F+\beta 2 E+\beta 3 L+\beta 4 I+$ $\mathbf{U}$

Key;

$\mathrm{Y}_{\mathrm{LD}}=$ Loan Defaults

$\beta 0=$ Constant

$\beta 1 \mathrm{~F}=$ Financial Factors

$\beta 2 \mathrm{E}=$ Economic Factors

$\beta 3 \mathrm{~L}=$ Loan usage Factors

$\beta 4 \mathrm{I}=$ Institutional Factors

$\mathrm{U}=$ Error term

The correlation matrix used to measure the relationship between two variables and the impact of those variables on NPL is measured using multiple regression analysis.

The sample characteristics are depicted in table 1 .

\section{Table 1. Sample Distribution}

\begin{tabular}{llcc}
\hline Dimension & Subject & $\begin{array}{r}\text { Frequenc } \\
\text { y }\end{array}$ & $\begin{array}{c}\text { Percenta } \\
\text { ge \% }\end{array}$ \\
\hline Gender & Male & 96 & $59 \%$ \\
\cline { 2 - 4 } & Female & 68 & $41 \%$ \\
\hline Civil Status & Married & 94 & $57 \%$ \\
\cline { 2 - 4 } & Single & 70 & $43 \%$ \\
\hline Age Composition & Between 18-30 Years & 29 & $18 \%$ \\
\cline { 2 - 4 } & Between 31-40 Years & 39 & $24 \%$ \\
\cline { 2 - 4 } & Between 41-50 Years & 41 & $25 \%$ \\
\cline { 2 - 4 } & Between 51-60 Years & 30 & $18 \%$ \\
\cline { 2 - 4 } & Between 61-70 Years & 25 & $15 \%$ \\
\hline Educational Qualifications & G.C.E.(O/L) & 25 & $15 \%$ \\
\cline { 2 - 4 } & For G.C.E. (A/L) & 32 & $19 \%$ \\
\cline { 2 - 4 } & Certificate Level & 41 & $25 \%$ \\
\cline { 2 - 4 } & Diploma & 37 & $23 \%$ \\
\cline { 2 - 4 } & Degree and Above & 29 & $18 \%$ \\
\hline Loan Borrowing Times & Single & 59 & $62 \%$ \\
\cline { 2 - 4 } & More than one time & 102 & $38 \%$ \\
\hline
\end{tabular}

As depicted in the table, a major portion of the respondents is male representing $59 \%$ of the sample. Out of the respondents, $57 \%$ are married customers and $62 \%$ have borrowed loans more than once.

Table 2. Reliability Testing

\begin{tabular}{ll}
\hline Variable & $\begin{array}{l}\text { Cronbach's } \\
\text { Alpha }\end{array}$ \\
\hline Financial Factors & .869 \\
\hline Economic Factors & .852 \\
\hline Loan usage Factors & .858 \\
\hline Institutional Factors & .859 \\
\hline Loan Defaults & .884 \\
\hline
\end{tabular}


The reliability of the variables is closer to or greater than the accepted minimum level of 0.60 . (Sekaran \& Bougie, 2010) Accordingly, the reliability test results verify that the questionnaire developed had measured the variables unfailingly.

Table 3. Correlation Analysis

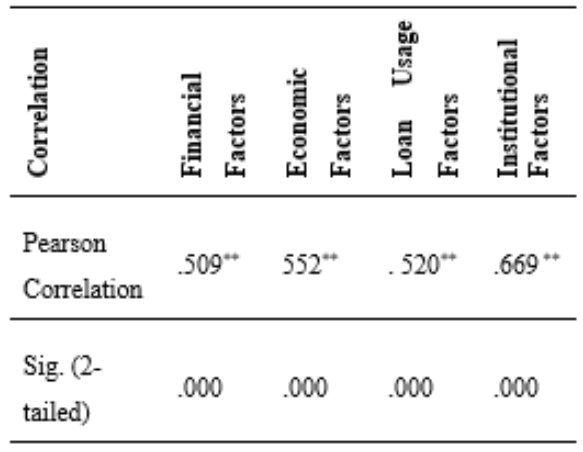

As table 3 depicted the institutional factors have the highest significant relationship with the loan defaults with a Pearson's Correlation value of 0.669. Economic factors $(r=.552)$, loan usage factors $(\mathrm{r}=.520)$ and financial factors $(r=.509)$ shows a significant relationship with NPL respectively.

Table 4. Regression Results

\begin{tabular}{lccc}
\hline Model & \multicolumn{2}{c}{$\begin{array}{c}\text { Unstandardized } \\
\text { Coefficients }\end{array}$} & $\begin{array}{c}\text { Standardized } \\
\text { Coefficients }\end{array}$ \\
\cline { 2 - 4 } & B & Std. Error & Beta \\
\hline & .386 & .197 & \\
$\quad$ (Constant) & .058 & .077 & .065 \\
$\quad \begin{array}{l}\text { Financial Factors } \\
\text { Economic Factors }\end{array}$ & .135 & .118 & .116 \\
$\quad \begin{array}{l}\text { Loan usage } \\
\text { Factors }\end{array}$ & .094 & .120 & .078 \\
$\begin{array}{l}\text { Institutional } \\
\text { Factors }\end{array}$ & $.558^{*}$ & .088 & .506 \\
\hline
\end{tabular}

\begin{tabular}{|c|c|c|c|c|}
\hline \multirow{4}{*}{2} & (Constant) & $.390^{*}$ & .197 & \\
\hline & Economic Factors & .152 & .115 & .132 \\
\hline & $\begin{array}{l}\text { Loan usage } \\
\text { Factors }\end{array}$ & .121 & .114 & .101 \\
\hline & $\begin{array}{l}\text { Institutional } \\
\text { Factors }\end{array}$ & $.576^{*}$ & .085 & .522 \\
\hline \multirow{3}{*}{3} & (Constant) & $.435^{*}$ & .192 & \\
\hline & Economic Factors & $.232^{*}$ & .087 & .201 \\
\hline & $\begin{array}{l}\text { Institutional } \\
\text { Factors }\end{array}$ & $.593^{*}$ & .083 & .538 \\
\hline
\end{tabular}

Table 4 illustrate the $B$ values of the variables and their significance. According to the backward method model summary of regression analysis B reflects a positive relationship between economic factors and loan defaults among the multiple variable models 1,2 , and 3 respectively are $0.135,0.152$, and 0.232 . According to model 3, there was a positive relationship between economic factors and loan defaults that shows $23 \%$. It is evident that economic factors significantly impact loan defaults.

According to the backward method model summary of regression analysis $B$ reflects a positive relationship between institutional factors and loan defaults among the multiple variable models 1,2 , and 3 respectively is $0.558,0.576$, and 0.593 . According to model 3, there was a positive relationship between institutional factors and loan defaults that shows $59 \%$. It is too evident that institutional factors significantly impact loan defaults.

According to the model 1 summary of regression analysis $B$ reflects a positive relationship between financial factors and loan defaults among the multiple variables, which is 0.058 . So there was a positive weakest 
relationship between financial factors and loan defaults that shows $6 \%$. The significant value model 1 is 0.451 . As per the results, it can be stated that the financial factors do not significantly impact loan defaults.

Table 5. Model Summary

\begin{tabular}{|c|c|c|c|}
\hline 丞 & $\mathscr{4}$ & 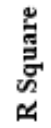 & 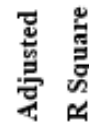 \\
\hline
\end{tabular}

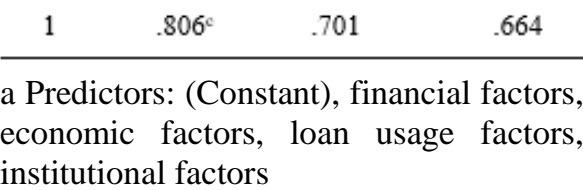

Finally, according to the model summary of regression analysis B reflects a positive relationship between loan usage factors and loan defaults among the multiple variables. It shows models 1 and 2 respectively 0.094 and 0.121 . The significant values are models 1 and 2 respectively $0.435,0.288$. Here loan usage factors are not significant on loan defaults as depicted by the regression results.

The $\mathrm{R}^{2}$ value of the regression model accounts for 0.702 which represent the four predictor variable can account for $70.2 \%$ of the variation in loan defaults.

\section{DISCUSSION}

According to the regression results, it is evident that only economic factors and institutional factors were able to regress with NPL. The other two factors even though they had a positive correlation with NPL, failed to regress with NPL.
Table 6. Summary

\begin{tabular}{lll}
\hline Variable & B Value & Decision \\
\hline Constant & 0.435 & \\
\hline Financial Factors & 0.058 & H1 Rejected \\
\hline Economic Factors & $0.232^{*}$ & H2 Accepted \\
\hline Loan usage Factors & 0.121 & H3 Rejected \\
\hline Institutional Factors & $0.593^{*}$ & H4 Accepted \\
\hline
\end{tabular}

As depicted in table 6, the financial factors fail to have a significant $\mathrm{P}$ value. There isn't enough evidence to reject the null hypothesis. It tells that financial factors do not significantly impact loan defaults. Therefore, this hypothesis is rejected.

The economic factors are able to maintain a significant coefficient in all three models. Therefore, it provides enough evidence to reject the null hypothesis which allows accepting alternative hypothesis which tells that there was a significant impact on economic factors on loan defaults. Thus the result of this study confirms this hypothesis.

The loan usage Factor P-value is 0.435 . Since the given $P$ value was greater than 0.05 . There isn't enough evidence to reject the null hypothesis. It tells that there is it tells that loan usage factors do not impact loan defaults. Therefore, this hypothesis is rejected.

The institutional factor of all three models provided enough evidence to reject the null hypothesis which gives evidence to accept the alternative 
hypothesis which tells that there was a significant impact on institutional factors on loan defaults. Thus the result of this study confirms this hypothesis.

Consequently, the following regression model was constructed based on the analysis.

$$
Y_{L D}=0.435+0.232 E+0.593 I+U
$$

The value of $\mathrm{R}^{2}$ in this model is 0.702 . That represents the four predictor variable can account for $70.2 \%$ of the variation in loan defaults. There might be many factors that can explain this variation. However, the current model which includes only financial factors, economic factors, loan usage factors, and institutional factors that can explain approximately $70.2 \%$.

The adjusted $\mathrm{R}^{2}$ value explains how much variance in the dependent variable would be accounted for if the model has been derived from the population from which the sample was taken. Also adjusted $\mathrm{R}^{2}$ gives us some idea of how well this model can be generalized and ideally it would like its value to be the same or very close to the value of $\mathrm{R}^{2}$ (Field, 2009). The current study is $\mathrm{R}^{2}$ is 0.702 and the adjusted $\mathrm{R}^{2}$ of this study is 0.664 .

In this study, the researcher could find out that the most influential dimensions which influence the loans defaults are institutional factors and economic factors. According to the regression analysis, they have a significant positive relationship with loan defaults.

\section{CONCLUSION}

The objective of this research was to identify the factors affecting loan defaults with special reference to state commercial banks in the Kegalle district. The results showed that, based on the respondents' view, it was evident that most likely factors that affect occurrences of nonperforming loans in-state commercial banks in the Kegalle district.

Ultimately, this study concluded that institutional factors are the most influential factor in loan default in compliance with the findings of Bloem \& Gorter, (2001); Berger \& De Young (1997). Based on the findings of the research, state commercial banks need more pay attention to their management team and the staff members. Besides, despite the fact that lenient credit term and monitoring/ follow-up plays a pivotal role to ensure loan collection failure to do this properly was also found to be causes for loan defaults. Cases of underfinancing loan requirements that meant a shortage of working capital or not being able to meet planned targets were associated with defaults.

Further, it could be concluded that economic factors have an impact on loan defaults. Economic factors are a common impact on the banking industry to create non-performing loans. Inflation rates and unemployment situation (income) are the majority impacted to the loan defaults in economic factors which confirms with the findings of Warue (2013); Jimenez \& Saurina (2006); and Nkusu (2011). Therefore, state commercial banks need special 
attention regarding economic factors when they grant loans to customers to prevent non-performing loans. In the current study, other factors such as financial factors and loan usage factors had few impacts respectively on the loan defaults. Based on the findings the researcher could draw the conclusion that non-performing loans are mainly caused by institutional factors and economic factors.

Therefore, state commercial banks in Kegalle need to continue to strengthen their credit risk mitigation measures to maintain the stability of the banking sector. As such, it is essential for banks to carry out a proper evaluation of credit applications and closely monitor repayment capacity and cash flow of the borrowers to ensure that expansion of credit will not pose a further risk to financial system stability. Resolution on performing loans in countries like Sri Lanka ultimately lies in developing a competitive environment for the financial sector as a whole.

After analyzed of the research findings, the following recommendations are suggested by the researcher: Banks should put in place a vibrant credit process that would encompass issues of proper customer selection, robust credit analysis, proactive monitoring, and follow up and clear recovery strategies to prevent non-performing loans in-state commercial banks.

Banks should put in place a clear policy framework that addresses issues of conflict of inflation rates, income level, and cost of living in the decision-making process for all those involved in the credit process to ensure its implementation thereof.

The study further recommends that there is a need for state commercial banks to initiate policies that will control the number of loans they have.

Direction for future researchers is as such that this study was focused only on four factors affecting loan defaults where a further study can be carried out by including more variables to the regression model. The study can be further expanded by including both public and private sector banks and expanding the geographical area.

\section{REFERENCES}

Ahmad, N.H., 2002. FINANCIAL CRISIS AND NONPERFORMING LOANS: The Malaysian Banks Experience. International Journal of Finance, 14(2).

Berger, A.N. and DeYoung, R., 1997. Problem loans and cost efficiency in commercial banks. Journal of Banking \& Finance, 21(6), pp.849-870.

Bloem, A.M. and Gorter, C., 2001. The treatment of nonperforming loans in macroeconomic statistics (Vol. 1). Washington, DC: International Monetary Fund.

Board, F.S., 2009. Report to G20 finance ministers and governors guidance to assess the systemic importance of financial institutions, markets and instruments: Initial considerations. 
Bloem, A.M. and Gorter, C., 2001. The treatment of nonperforming loans in macroeconomic statistics (Vol. 1). Washington, DC: International Monetary Fund.

Board, F.S., 2009. Report to G20 finance ministers and governors guidance to assess the systemic importance of financial institutions, markets and instruments: Initial considerations.

Demirgüç-Kunt, A. and Detragiache, E., 1998. The determinants of banking crises in developing and developed countries. Staff Papers, 45(1), pp.81-109.

Field, A., 2009. Discovering statistics using SPSS:(and sex and drugs and rock'n'roll). Sage.

Gonzalez-Hermosillo, B., 1999. Determinants of ex-ante banking system distress: A macro-micro empirical exploration of some recent episodes.

Gorter, N. and Bloem, M., 2002. The macroeconomic statistical treatment of NPLs. Publication of the Organization for Economic corporation \& Development.

Jiménez, G. and Saurina, J., 2018. Credit Cycles, Credit Risk, and Prudential Regulation-IJCB-June 2006. Fifth issue (June 2006) issue of the International Journal of Central Banking.
Nkusu, M., 2011. Nonperforming loans and macrofinancial vulnerabilities in advanced economies. IMF Working Papers, pp.1-27.

Radha, M. and Vasudevan, S.V., 1980. A text book of banking: Law, practice and theory of banking. New Delhi: S, Chand \&Co. Ltd.

Sekaran, U. and Bougie, R., 2010. Research methods for business: A skill building approach. John Wiley \& Sons.

Warue, B.N., 2013. The effects of bank specific and macroeconomic factors on nonperforming loans in commercial banks in Kenya: A comparative panel data analysis. Advances in Management and Applied Economics, 3(2), p.135.

Woo, M.D., 2000. Two approaches to resolving nonperforming assets during financial crises. International Monetary Fund.

World Bank, W.B., 2014. LAC Poverty and Labor Brief, February 2014: Social Gains in the Balance-A Fiscal Policy Challenge for Latin America and the Caribbean. The World Bank. 